\title{
Probable Bexarotene Hepatotoxicity Associated With Transient Serum Antimitochondrial Antibodies
}

\author{
Howard J. Worman ${ }^{\mathrm{a}, \mathrm{b}}$
}

\begin{abstract}
Bexarotene is a retinoid $\mathrm{X}$ receptor agonist approved for the treatment of cutaneous manifestations of cutaneous T-cell lymphoma. In clinical trials, its use has been associated with elevations in serum aminotransferase activities. This report describes a case of probable bexarotene-induced hepatocellular injury in a woman, which was originally misdiagnosed as primary biliary cirrhosis because of the transient presence of serum antimitochondrial antibodies. Liver biopsy showed portal and periportal inflammation, ceroid-laden macrophages and normal bile ducts. Serum aminotransferase activities returned to normal approximately 8 weeks after discontinuing bexarotene and serum antimitochondrial antibodies were not detectable approximately one year after stopping the drug. This case reinforces the need to consider the possibility of drug-induced liver injury in patients taking bexarotene and that serum antimitochondrial antibodies may be transiently detectable in such individuals.
\end{abstract}

Keywords: Bexarotene; Hepatotoxicity; Antimitochondrial antibodies; Cutaneous T-cell lymphoma; Alzheimer disease

\section{Introduction}

Bexarotene (Targretin ${ }^{\circledR}$, Eisai Inc., Woodcliff Lake, NJ) is a retinoid $\mathrm{X}$ receptor-selective, antitumor retinoid approved by the U.S. Food and Drug Administration for the oral treatment

Manuscript accepted for publication April 4, 2012

\footnotetext{
${ }^{a}$ Department of Medicine and Department of Pathology and Cell Biology, College of Physicians and Surgeons, Columbia University, New York, NY 10032, USA

${ }^{\mathrm{b}}$ Corresponding address: Department of Medicine, College of Physicians and Surgeons, Columbia University, 630 West 168th Street, 10th Floor, Room 509, New York, NY 10032, USA.

Email: hjw14@columbia.edu
}

doi:10.4021/jmc633w of cutaneous T-cell lymphoma in patients who are refractory to at least one prior systemic therapy [1]. In addition, bexarotene has received considerable recent attention because of a study claiming that it can clear beta-amyloid and reverse cognitive, social and olfactory deficits in a murine model of Alzheimer disease [2]. In clinical trials for cutaneous T-cell lymphoma, elevations in serum aminotransferase activities have been observed in up to $9 \%$ of subjects taking the drug with one possible case of liver failure [3-5]. Other than data from clinical trials and the manufacturer's package insert, there are no published cases on the presentation and features bexarotene-induced liver injury. This report describes a case of probable drug-induced liver injury in a woman with lymphomatoid papulosis who received bexarotene. Concurrent with acute drug-induced liver injury, the patient had transiently detectable serum antimitochondrial antibodies, leading to an initial misdiagnosis of primary biliary cirrhosis.

\section{Case Report}

The patient was a physically fit 40 year-old woman with no family history of liver disease who drank only minimal quantities of alcohol. She was referred to Columbia University Medical Center for a second opinion regarding a possible diagnosis of primarily biliary cirrhosis. At approximately 8 years of age, she was diagnosed with lymphomatoid papulosis and received various forms of treatment intermittently, including psoralen-ultraviolet A phototherapy. About 12 years prior to presentation, she underwent radioiodine thyroid ablation for hyperthyroidism and has taken 1-thyroxine since. At approximately age 40 she started treatment with bexarotene $(225 \mathrm{mg} /$ day $)$. Approximately one month after starting bexarotene, her serum alkaline phosphatase and aminotransferase activities were normal. Approximately 5 months after starting treatment, her serum alkaline phosphatase was normal but alanine aminotransferase (ALT) was elevated at $259 \mathrm{IU} / \mathrm{L}$ and aspartate aminotransferase (AST) elevated at $187 \mathrm{IU} / \mathrm{L}$; the serum bilirubin concentration was normal. At that time, her serum cholesterol was $262 \mathrm{mg} / \mathrm{dl}$ and serum triglycerides $395 \mathrm{mg} / \mathrm{dl}$ and she was started on fenofibrate. Approximately 8 months after starting bexaro- 
Table 1. CIOMS/RUCAM Scoring for Hepatotoxicity

\begin{tabular}{lll}
\hline Type of liver injury & Hepatocellular (first exposure) & Points \\
\hline Time of onset of the event & First exposure & + \\
Time from drug intake until reaction onset & $<5$ or $>90$ days & +2 \\
Course of the reaction & $>50 \%$ improvement 30 days & +0 \\
Risk factors & No & No \\
\multicolumn{1}{c}{ Alcohol } & Time to onset incompatible & +0 \\
Concomitant therapy & Ruled out & +2 \\
Exclusion of nondrug-related causes & Reaction labeled in product's characteristics & +2 \\
Previous information on hepatotoxicity & Not available & +0 \\
\hline Response to re-administration & Probable & +7 \\
\hline
\end{tabular}

tene, alkaline phosphatase was normal but her serum ALT activity was elevated at $231 \mathrm{IU} / \mathrm{L}$ and AST activity elevated at $260 \mathrm{IU} / \mathrm{L}$. Bexarotene and fenofibrate were discontinued and tests for hepatitis B surface antigen and antibodies against hepatitis $\mathrm{C}$ virus were negative. About two weeks after discontinuing bexarotene, the patient's serum alkaline phosphatase activity remained normal and her AST activity was $61 \mathrm{IU} / \mathrm{L}$, ALT activity $88 \mathrm{IU} / \mathrm{L}$ and an ELISA for antimitochondrial M2 antibodies (performed at LabCorp) was positive (64.5 units). Approximately, six weeks after discontinuing bexarotene, her serum alkaline phosphatase, AST and ALT activities were normal and a repeat test for antimitochondrial M2 antibodies (performed at LabCorp) was again positive (49.2 units); a test for antinuclear antibodies was negative. A liver biopsy at that time showed portal and periportal inflammation and ceroid-laden macrophages primarily in centrilobular regions but the bile ducts were completely normal. The histological findings were most consistent with a resolving acute injury, such as a drug-induced injury. Two months after her liver biopsy, the patient's serum alkaline phosphatase activity was again normal and her serum immunoglobulin $\mathrm{M}$ concentration was normal. Approximately one year and again approximately 14 months after discontinuing bexarotene, tests for antimitochondrial antibodies (performed at Warde Medical Laboratory) were negative. Use of the CIOMS/RUCAM scale [6] predicted it was probable that the patient's liver damage was attributed to bexarotene (Table 1).

\section{Discussion}

This case report emphasizes the possibility of an acute hepatocellular injury induced by bexarotene. Elevations in serum aminotransferase activities have been reported in clinical trials and are noted in the package insert for this drug. One case of liver failure was reported in a clinical trial of bexarotene; however, the patient had multiple possible etiologies for liver failure and the clinical picture was cholestatic without evidence of hepatocellular injury [3]. Otherwise, there have been no case reports in the medical literature describing the clinical presentation and features of a patient with bexarotene-induced hepatocellular toxicity.

The patient described in this case report was referred for a second opinion regarding a possible diagnosis of primary biliary cirrhosis, which was prompted by the detection of serum antimitochondrial antibodies soon after she discontinued bexarotene. A diagnosis of primary biliary cirrhosis was essentially eliminated because she never had an abnormally elevated serum alkaline phosphatase activity, did not have an elevated serum immunoglobulin $\mathrm{M}$ concentration and did not have any consistent histological features on liver biopsy. Approximately one year after discontinuing bexarotene, serum antimitochondrial antibodies were no longer detectable. Serum antimitochondrial antibodies are detected in approximately $40 \%$ of subjects with acute liver failure from a variety of causes, with disappearance in most subjects within one year after resolution [7]. Transiently detectable serum 
antimitochondrial antibodies have also been reported in subjects with liver damage presumably induced by Teucrium chamaedrys (germander) [8] and an anticonvulsant [9]. In addition, antibodies against various cytosolic organelles, including mitochondria, have been reported in hepatitis induced by a variety of other drugs [10].

No single case report can prove cause and effect. Another limitation of this report is that antimitochondrial antibodies were measured in clinical reference laboratories and not in a research laboratory where reactivity to specific protein epitopes can be determined. Nonetheless, this case provides further evidence that bexarotene can induce liver injury in susceptible individuals. It also suggests that various types of liver damage could potentially lead to the generation of antimitochondrial antibodies but, as hypothesized by Leung et al [7], the pathogenesis of primary biliary cirrhosis requires additional factors.

\section{Conflict of Interest}

None.

\section{Declaration of Funding}

None.

\section{References}

1. Hurst RE. Bexarotene ligand pharmaceuticals. Curr Opin Investig Drugs. 2000;1(4):514-523.

2. Cramer PE, Cirrito JR, Wesson DW, Lee CY, Karlo JC, Zinn AE, Casali BT, et al. ApoE-directed therapeutics rapidly clear beta-amyloid and reverse deficits in $\mathrm{AD}$ mouse models. Science. 2012;335(6075):1503-1506.

3. Duvic M, Hymes K, Heald P, Breneman D, Martin AG, Myskowski P, Crowley C, et al. Bexarotene is effective and safe for treatment of refractory advanced-stage cutaneous T-cell lymphoma: multinational phase II-III trial results. J Clin Oncol. 2001;19(9):2456-2471.

4. Duvic M, Martin AG, Kim Y, Olsen E, Wood GS, Crowley CA, Yocum RC. Phase 2 and 3 clinical trial of oral bexarotene (Targretin capsules) for the treatment of refractory or persistent early-stage cutaneous T-cell lymphoma. Arch Dermatol. 2001;137(5):581-593.

5. Package Insert Targretin $\AA$ (bexarotene) capsules, 75 mg [Targretin Web site]. May 2007. Available at: http:// www.targretin.com. Accessed March 2, 2012.

6. Danan G, Benichou C. Causality assessment of adverse reactions to drugs--I. A novel method based on the conclusions of international consensus meetings: application to drug-induced liver injuries. J Clin Epidemiol. 1993;46(11):1323-1330.

7. Leung PS, Rossaro L, Davis PA, Park O, Tanaka A, Kikuchi K, Miyakawa H, et al. Antimitochondrial antibodies in acute liver failure: implications for primary biliary cirrhosis. Hepatology. 2007;46(5):1436-1442.

8. Polymeros D, Kamberoglou D, Tzias V. Acute cholestatic hepatitis caused by Teucrium polium (golden germander) with transient appearance of antimitochondrial antibody. J Clin Gastroenterol. 2002;34(1):100-101.

9. Watanabe K, Tanaka Y, Takemura T, Naitoh M, Hata Y, Kino K, Tsuru M, et al. [A case of anticonvulsive druginduced liver injury accompanied by a transient appearance of antimitochondrial antibody, M2]. Nihon Shokakibyo Gakkai Zasshi. 1998;95(3):246-249.

10. Homberg JC, Abuaf N, Helmy-Khalil S, Biour M, Poupon $\mathrm{R}$, Islam S, Darnis F, et al. Drug-induced hepatitis associated with anticytoplasmic organelle autoantibodies. Hepatology. 1985;5(5):722-727. 